\title{
RESEARCH
}

Open Access

\section{Physiological role of thiamine and weed control treatments on faba bean and associated weeds grown under salt affected soil}

Ibrahim M. El-Metwally and Mervat Shamoon Sadak* (1)

\begin{abstract}
Background and objective: Salinity stress is an important abiotic stress that affect adversely on crop production, so using of natural compounds to improve plant tolerance to stress is very important.

Materials and methods: Two field experiments were conducted during two winter seasons of 2014/2015 and 2015/2016 at Tag El-Ezz Research Station of Agricultural Research Centre, Dakahliea Egypt. Field evaluation of the efficiency of weed-control treatments (unweeded, oxadiargyl, and two hand hoeing) and thiamine levels $(0,50,75$, and $100 \mathrm{mg} / \mathrm{l})$ and their interactive effects on weeds, faba bean growth, yield, yield attributes, and some

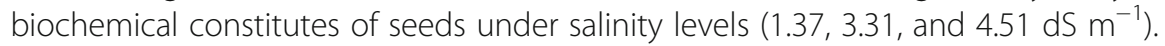

Results: Data revealed that number and dry weight of broad-leaved, narrow-leaved, and total weeds were significantly reduced by increasing salinity levels of soil from 1.37 to $4.51 \mathrm{dS} \mathrm{m}^{-1}$. In addition, the highest salinity level $4.51 \mathrm{dS} \mathrm{m}^{-1}$ caused the highest significant decreases in growth, yield, and yield attributes of faba bean.

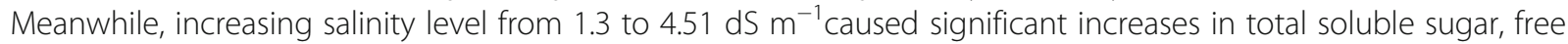
amino acids, and proline contents of faba bean plant. Two hand hoeing treatment achieved the highest weed depression expressed in the lowest dry matter of total weeds. Also, two hand hoeing was the most effective weed control treatment in increasing growth, yield, yield attributes, and some biochemical constitutes of faba bean seeds followed by of oxadiargyl treatment. No significant differences between application of two hand-hoeing and oxadiargyl treatment on all studied parameters. Foliar treatment of faba bean plants with thiamine different concentrations could alleviate the harmful effects of different salinity levels.

Conclusion: We could conclude that foliar application of thiamine at the rate of $100 \mathrm{mg} / \mathrm{l}$ caused the highest increases in all growth and yield parameters under investigation of faba bean plant. Interaction of $100 \mathrm{mg} / \mathrm{l}$ thiamine treatment and two hand hoeing was the most effective treatments on enhancing faba bean growth, yield, and its attributes under salinity levels. Results also indicated that free amino and proline works to increase faba bean plants ability to withstand salinity stress.
\end{abstract}

Keywords: Biochemical constituents, Faba bean, Salinity, Seed yield, Thiamine and weeds

* Correspondence: mervat_sh24@yahoo.com

Botany Department, Agricultural and Biological Division, National Research

Centre, 33 El-Bohooth st., (former El-Tahrir st.), Dokki, Cairo 12622, Egypt 


\section{Introduction}

Soil salinity is a major problem in agriculture throughout the world. The major constraints for plant growth and productivity is ion toxicity via excessive uptake of mainly $\mathrm{Cl}^{-}$and $\mathrm{Na}^{+}$as well as nutrients imbalance caused by disturbed uptake of essential mineral nutrients (Hu and Schmidhalter 2005). Ghassemi et al. (1995) reported that in Egypt, the area of salt-affected irrigated land is about $33 \%$. Salinity is a complex environmental constraint that presents adverse effects on plant cells due to the decrease in external osmotic potential of soil solution and an ionic component linked to accumulation of ions which becomes toxic at high concentrations. The toxic effect of salt stress lead to adverse metabolic changes such as loss of chloroplast activity, decreased photosynthetic rate, and increased photorespiration rate which leads to an increased reactive oxygen species (ROS) production (Parida and Das 2005).

Salinity continues to be one of the world's most serious environmental problems because elevated levels of $\mathrm{NaCl}$ are naturally present in many agricultural fields. Global scarcity of water resources and salinization increasing of soil and water are the main reducing factors of agricultural productivity. Crop performance might be adversely affected by salinity as a result of nutritional disorders. These disorders might be derived from the effect on nutrient availability, competitive uptake, transport, or partitioning within the plant (Silva et al. 2008). Living with salinity is the only way of sustaining agricultural production in salt affected soil (Al-Rawahy et al. 2011). Plants that are naturally exposed to salt stress can adapt their metabolism to cope with the changed environment. To maintain water uptake for growth and turgor, plant internal water potential must keep below of the soil. This maintenance needs uptake of soil solutes or the synthesis of compatible solutes to increase the osmotica potential (Ashraf 2010). These organic solutes are highly soluble and low molecular weight that do not intermediate with metabolism of plants and at high cellular concentrations, these compounds are nontoxic (El-Bassiouny et al. 2017). Such compatible osmolytes increase uptake of water from the environment. Thus, buffering the immediate effect of water deficiency inside plant cells. Also, these solutes are called osmoprotectants because of its protection role in cellular components from injury of dehydration during stress. These osmoprotectants include set of proteins, amino acids, and soluble sugars (Ashraf 2010). External application of some antioxidants, vitamins, amino acids, etc. can alleviate the reduced effect of salinity. Seed priming or foliar treatment of antioxidants and vitamins can be one of the economically viable strategies to increase plant tolerance to stress (Senaratna et al. 2000).
Vitamins could be considered as bio-regulators or hormone precursors compounds which in small quantities exert an effective influence upon plant growth. In general, energy metabolic pathway could be affected by one or another of these substances (Robinson 1973). Recently, it was suggested that all vitamins participate in plant growth and development. Most studies showed that most essential physiological processes such as photosynthesis, building of all organic foods and enzymes, nutrient, and water uptake and cell division depends more or less on the availability of vitamins (Robinson 1973). Vitamins with their antioxidative properties play an important role in plant defense against oxidative stress induced by all chemicals as it act as free radicals scavenger. The beneficial effect of vitamins was attributed to their positive action on enhancing cell division and various growth factors, such as cytokinins and gibberellins (Oertli 1997; Samiullah et al. 1988; Bertschinger and Stadler 1997).

Thiamine (vitamin $B_{1}$ ) is one of vitamin $B$ group that could serve as coenzyme in decarboxylation of $\alpha$-keto acids, such as pyruvic acid and keto-glutamic acid which has its importance in the metabolism of carbohydrates and fats (Bidwell 1979). Thiamine is an important cofactor for the transketolation reactions of the pentose phosphate cycle, which provides pentose phosphate for nucleotide synthesis and for the reduced nicotinamide adenine dinucleotide phosphate (NADP) required or various synthetic pathways (Kawasaki 1992). Youssef and Talaat (2003) reported that pronounced increases in vegetative growth and chemical constituents of rosemary plants by foliar application of thiamine. The data of Abdel Aziz et al. (2009) emphasized that application of thiamine significantly increased growth parameters and yield of Gladiolus plant. The highest values of results were obtained in plants treated with $100 \mathrm{ppm}$ thiamine. Thiamine is a necessary ingredient for the biosynthesis of the coenzyme thiamine pyrophosphate; in this latter form, it plays an important role in carbohydrate metabolism. It is an essential nutrient for both plants and animals. In plants, it is synthesized in the leaves and is transported to the roots where it controls growth (Kawasaki 1992).

Faba bean (Vicia faba L.) is an important food crop in Egypt grown in winter season. It is a good source of protein for human food and animal feeding as its seeds contain most of the necessary amino acids for human and animal nutrition and low sulfur amino acids concentrations. In addition, faba bean plants improve soil fertility by providing a substantial input of $\mathrm{N}_{2}$ fixation. The government encourages production of new improved faba bean cultivars and application of high productivity cultivation methods.

Weeds are considered a major problem in bean crop production causing great losses in seed yield due to 
direct weed-plant competition for light, moisture, and soil nutrients. The increase in faba bean crop yield as a result of weed control reached about 78\% (El-Metwally and Shalby 2007). Thus, weed control is one of the most essential cultural practices for raising faba bean yield and improving its quality. Two hand hoeing are recommended for effective weed control in faba bean. Hand hoeing treatment in faba bean fields is the most widespread method of weed control, resulting in good control of weeds (El -Metwally and Abdelhamid 2008). Using chemical weed management in intensively grown crops (e.g., faba bean) is easier and more economical than manual or mechanical ones, especially after hand labors scarce and pay rise. But under the warnings against manipulating herbicides recently, the supply of their authorized components became extremely restricted.

Therefore, this work aimed to study effect of foliar application of thiamine, weed control treatments, and their interactions on some growth traits, chemical composition of shoot and seed, as well as seed yield of faba bean plants and its associated weeds grown under saline and non-saline soil conditions.

\section{Materials and methods}

\section{Experimental procedures}

Two field experiments were conducted during two successive growing seasons 2014/15 and 2015/16 at Tag ElEzz Research Station of Agricultural Research Centre, Dakahliea Egypt ( $30^{\circ} 57^{\prime} 24^{\prime \prime} \mathrm{N} 31^{\circ} 35^{\prime} 53^{\prime \prime}$ E). Seeds of faba bean (Vicia faba L., cv. Giza-843) obtained from Agricultural Research Centre, Egypt, were sown on 17th and 19th November and harvest at 27th and 30th April for the two growing seasons. Faba bean seeds were selected for uniformity by choosing those of equal size and with the same color. The selected seeds were washed with distilled water, sterilized with $1 \%$ sodium hypochlorite solution for about $2 \mathrm{~min}$, and thoroughly washed again with distilled water and, left to dry at room temperature $\left(25^{\circ} \mathrm{C}\right)$ for about $1 \mathrm{~h}$. Faba bean seeds were inoculated with the specific Rhizobium strain and immediately three uniform air dried seeds were sown in hills $25 \mathrm{~cm}$ apart, on both sides of the ridge during the two growing seasons. Thinning was carried out at 15 days after sowing (DAS) to leave two plants per hill. Recommended amount of faba bean seeds of $150 \mathrm{~kg} / \mathrm{ha}$ were used. Physical and chemical analyses of the experimental soils were determined according to Chapman and Pratt (1978) as shown in Table 1. Recommended doses of chemical fertilizers (N, P, and $\mathrm{K}$ ) for faba bean production in this area were applied $\left(36 \mathrm{~kg} \mathrm{ha}^{-1} \mathrm{~N}+75 \mathrm{~kg} \mathrm{ha}^{-1}\right.$ $\mathrm{P}_{2} \mathrm{O}_{5}+50 \mathrm{~kg} / \mathrm{ha} \mathrm{K}_{2} \mathrm{O}$ ). The experiments were laid out in strip-spilt plot design with four replicates. Sub-sub plot area was $10.5 \mathrm{~m}^{2}$ included five rows, $0.6 \mathrm{~m}$ wide and $3.5 \mathrm{~m}$ long. The main plots were allocated for salinity levels $\left(1.37,3.31\right.$, and $4.51 \mathrm{dS} \mathrm{m}^{-1}$ (considered as S1, S2, and $\mathrm{S} 3$, respectively), whereas the sub-plots were occupied weed control treatments and the sub-sub plots were devoted to the foliar application with thiamine levels. Weed control were unweeded (UW), two hand hoeing $(2 \mathrm{HH})$ at 3 and 6 weeks after sowing, and oxadiargyl, commercially known as Topstar, sprayed at preemergence at the rate of $600 \mathrm{~g} \mathrm{ha}^{-1}\left(480 \mathrm{~g} \mathrm{ha}^{-1}\right.$ active principle) after planting and before irrigation. Freshly prepared solution of thiamine levels $(0,50,75$, and $100 \mathrm{mg} / \mathrm{l}$ ) were exogenously applied at 30 and 45 days after sowing. The normal cultural practices of growing faba bean plants were followed.

\section{Measurements}

Weeds of $1 \mathrm{~m}^{2}$ from the middle ridge of each experimental unit were hand pulled at 60 days after sowing (DAS). The number and dry weights of broad-leaved and narrow-leaved weeds were estimated. The dry weight was recorded after oven drying at $70{ }^{\circ} \mathrm{C}$ for $72 \mathrm{~h}$.

At 60 and 90 DAS (vegetative growth stage), ten random faba bean plants were taken from each experimental plot to measure plant height, shoot dry weight $(\mathrm{g}$ plant $^{-1}$ ), and leaf area index (LAI). Biochemical aspects measured were SAPD value, proline, total free amino acids, total soluble sugars, total carbohydrates, and polysaccharides.

At harvesting, pods dry weight plant $^{-1}(\mathrm{~g})$, number of pods plant ${ }^{-1}$, number of seeds plant ${ }^{-1}$, weight of seeds plant $^{-1}$, and 100-seeds weight $(\mathrm{g})$ were recorded. The whole plot was harvested to determine seed yield $\left(\right.$ ton $\left.\mathrm{ha}^{-1}\right)$. The yielded seeds were cleaned and crushed

Table 1 Physical and chemical analyses of the experimental soil

\begin{tabular}{|c|c|c|c|c|c|c|c|c|c|c|c|c|c|c|}
\hline \multirow[t]{2}{*}{ Salinity } & \multirow[t]{2}{*}{$\mathrm{pH}$} & \multirow{2}{*}{$\begin{array}{l}\mathrm{EC} \\
(\mathrm{dS} / \\
\mathrm{m})\end{array}$} & \multicolumn{3}{|c|}{ Anions (meq L $\mathrm{L}^{-1}$ ) } & \multicolumn{4}{|c|}{ Cations (meq $\mathrm{L}^{-1}$ ) } & \multicolumn{5}{|c|}{ Particle size distribution (\%) } \\
\hline & & & $\overline{\mathrm{HCO}_{3}}{ }^{-}$ & $\mathrm{Cl}^{-}$ & $\overline{\mathrm{SO}_{4}{ }^{-}}$ & $\overline{\mathrm{Ca}^{++}}$ & $\mathrm{Mg}^{++}$ & $\mathrm{Na}^{+}$ & $\mathrm{K}^{+}$ & Coarse sand & Fine sand & Silt & Clay & Texture \\
\hline S1 & 7.93 & 1.35 & 3.04 & 13.4 & 4.95 & 6.1 & 3.9 & 11.3 & 0.54 & 5.7 & 17.3 & 40.2 & 36.8 & Clay \\
\hline S2 & 7.80 & 3.17 & 1.75 & 25.1 & 6.06 & 10.4 & 5.7 & 15.7 & 1.62 & 5.8 & 16.1 & 40.6 & 37.5 & Clay \\
\hline S3 & 7.97 & 4.20 & 2.12 & 31.6 & 7.46 & 12.0 & 6.1 & 21.0 & 1.67 & 5.6 & 15.9 & 40.7 & 37.8 & Clay \\
\hline
\end{tabular}

EC electrical conductivity

S1 $\left(1.37 \mathrm{dS} \mathrm{m}^{-1}\right), \mathrm{S} 2\left(3.31 \mathrm{dS} \mathrm{m}^{-1}\right), \mathrm{S} 3\left(4.51 \mathrm{dS} \mathrm{m}^{-1}\right)$ 
to determine some chemical constituents of seeds. Total nitrogen content of seeds was determined.

\section{Biochemical analysis SAPD value}

SAPD value was measured by chlorophyll meter (SPAD502 plus) according to Soil Plant Analysis Department Section, Minolta Camera Co., Osaka, Japan (Minolta Camera Co. 1989).

\section{Proline}

Proline and free amino acids contents were extracted according to the method described by Vartainan et al. 1992). Proline was assayed according to the method described by Bates et al. (1973). Two milliliters of proline extract, $2 \mathrm{ml}$ of acid ninhydrin, and $2 \mathrm{ml}$ of glacial acetic acid were added and incubated for $1 \mathrm{~h}$ in a boiling water bath followed by an ice bath. The absorbance was measured at $520 \mathrm{~nm}$ using Spekol Spectrocololourimeter VEB Carl Zeiss. A standard curve was obtained using a known concentration of authentic proline.

\section{Free amino acids}

Free amino acid was determined with the ninhydrin reagent method (Muting and Kaiser (1963). Then, $1.0 \mathrm{ml}$ acetate buffer ( $\mathrm{pH} 5.4$ ) and $1.0 \mathrm{ml}$ chromogenic agent were added to $1.0 \mathrm{ml}$ free amino acid extraction. The mixture was heated in boiling water bath for $15 \mathrm{~min}$. After cooled in tap water, $3 \mathrm{ml}$ ethanol $(60 \% v / v)$ was added. The absorbance at $570 \mathrm{~nm}$ was then monitored using Spekol Spectrocololourimeter VEB Carl Zeiss.

\section{Total soluble sugars}

Total soluble carbohydrates (TSS) were extracted by overnight submersion of dry tissue in $10 \mathrm{ml}$ of $80 \%(v / v)$ ethanol at $25{ }^{\circ} \mathrm{C}$ with periodic shaking, and centrifuged at $600 \mathrm{~g}$. The supernatant was evaporated till completely dried then dissolved in a known volume of distilled water to be ready for determination of soluble carbohydrates (Homme et al. 1992). TSS were analyzed by reacting of $0.1 \mathrm{ml}$ of ethanolic extract with $3.0 \mathrm{ml}$ freshly prepared anthrone (150 $\mathrm{mg}$ anthrone $+100 \mathrm{ml} 72 \%$ $\mathrm{H}_{2} \mathrm{SO}_{4}$ ) in boiling water bath for $10 \mathrm{~min}$ and reading the cooled samples at $625 \mathrm{~nm}$ using Spekol SpectrocololourimeterVEB Carl Zeiss (Yemm and Willis 1954).

\section{Total carbohydrates}

Determination of total carbohydrates was carried out according Dubois et al. (1956). A known mass (0.2-0.5 g) of dried tissue was placed in a test tube, and then $10 \mathrm{ml}$ of sulfuric acid $(1 \mathrm{~N})$ was added. The tube was sealed and placed overnight in an oven at $100{ }^{\circ} \mathrm{C}$. The solution was then filtered into a measuring flask $(100 \mathrm{ml})$ and completed to the mark with distilled water. The total sugars were determined colorimetrically according to the method ${ }^{18}$ as follows: an aliquot of $1 \mathrm{ml}$ of sugar solution was transferred into test tube and treated with $1 \mathrm{ml}$ of $5 \%$ aqueous phenol solution followed by $5.0 \mathrm{ml}$ of concentrated sulfuric acid. The tubes were thoroughly shaken for $10 \mathrm{~min}$ then placed in a water bath at 23$30{ }^{\circ} \mathrm{C}$ for $20 \mathrm{~min}$. The optical density of the developed color was measured at $490 \mathrm{~nm}$ using Shimadzu spectrophotometer model UV 1201. Polysaccharides were calculated by difference between total carbohydrates and total soluble sugars.

\section{Nitrogen and crude protein}

Total nitrogen content of seeds was determined with micro Kjeldhal's apparatus according to A. O. A. C. (1990). $N$ values were multiplied by 6.25 to calculate total crude protein.

All data were subjected to the analysis of variance (ANOVA) for a strip-spilt plot design, after testing for the homogeneity of error variances according to the procedure outlined by Gomez and Gomez (1984). Statistically significant differences between means were compared at $p \leq 0.05$ using least significant difference (LSD) test.

\section{Results}

\section{Changes in weed growth}

The most dominant weeds in both growing seasons were Wild beet (Beta vulgaris L.), Greater ammi (Amm imajus L.), Dock (Rumex dentatus L.), Bur clover (Medicago hispida L.), Annual yellow sweet clover (Melilotus indicus L.) as annual broad-leaved weeds, and Wild oat (Avena fatua L.) and Ryegrass (Lolium temulentum L.) as narrow-leaved weeds.

Results presented in Table 2 revealed that number and dry weight of broad-leaved, narrow-leaved, and total weeds were significantly reduced by increasing salinity level of soil. In this regard, $4.51 \mathrm{dS} \mathrm{m}^{-1}$ salinity level (S3) achieved the highest weed depression expressed in the lowest dry matter of the above mentioned weed groups.

Results in Table 2 clearly indicate that treatment of oxadiargyl was more efficient and exerted the highest reduction in dry weight of broad-leaved, narrow-leaved, and total weeds. It decreased dry weight of aforementioned characters by $83.49 \%, 83.51 \%$, and $83.50 \%$ at 60 DAS as compared with unweeded treatments. In this connection, oxadiargyl was more efficient and exerted the highest reduction in number of broad-leaved. While, two hand hoeing gave the lowest values of number of narrow-leaved and total weeds. Several reports have confirmed that hoeing twice is the most effective weed control practice for reducing weed dry matter accumulation in faba bean fields. Meanwhile, oxadiargyl was more effective in controlling total weeds and resulted in the 
Table 2 Effect of weed control and thiamine levels on number and dry weight $\left(\mathrm{g} / \mathrm{m}^{2}\right)$ of faba bean weeds at 60 days from sowing under salinity condition (combined analysis of two seasons)

\begin{tabular}{|c|c|c|c|c|c|c|}
\hline \multirow[t]{2}{*}{ Treatments } & \multicolumn{2}{|c|}{ Broadleaved } & \multicolumn{2}{|c|}{ Narrow leaved } & \multicolumn{2}{|c|}{ Total weeds } \\
\hline & No. & Weight & No. & Weight & No. & Weight \\
\hline \multicolumn{7}{|l|}{ Salinity levels $\left(\mathrm{dS} \mathrm{m}^{-1}\right)$} \\
\hline 1.37 & 18.2 & 22.3 & 26.8 & 22.5 & 45.0 & 46.9 \\
\hline 3.31 & 15.6 & 19.4 & 24.2 & 22.0 & 39.8 & 41.4 \\
\hline 4.51 & 11.1 & 13.7 & 17.1 & 15.7 & 28.2 & 29.4 \\
\hline LSD 0.05 & 2.1 & 3.2 & 1.8 & 1.6 & 3.4 & 3.9 \\
\hline \multicolumn{7}{|l|}{ Weed control: } \\
\hline Unweeded & 33.4 & 41.2 & 47.9 & 46.7 & 81.3 & 87.9 \\
\hline Oxadiargyl & 5.5 & 6.8 & 11.2 & 7.7 & 16.7 & 14.5 \\
\hline Two hand hoeing & 6.0 & 7.4 & 8.6 & 7.8 & 14.6 & 15.3 \\
\hline LSD 0.05 & 1.3 & 1.5 & 2.2 & 2.5 & 1.8 & 2.5 \\
\hline \multicolumn{7}{|l|}{ Thiamine levels (mg/l) } \\
\hline Control & 13.5 & 15.5 & 20.6 & 18.9 & 34.1 & 35.4 \\
\hline 50 & 14.5 & 17.9 & 22.3 & 20.4 & 36.8 & 38.3 \\
\hline 75 & 15.7 & 19.4 & 23.6 & 21.6 & 39.3 & 41.0 \\
\hline 100 & 16.2 & 20.9 & 24.2 & 22.1 & 40.5 & 42.1 \\
\hline LSD 0.05 & NS & 1.3 & NS & 2.1 & NS & 2.1 \\
\hline
\end{tabular}

highest reduction of dry matter when compared with unweeded treatments. No significant differences between application of two hand-hoeing and oxadiargyl treatments on growth of weeds. With respect to thiamine treatments, thiamine application at the rate of $100 \mathrm{mg} / \mathrm{l}$ caused significant increases in dry weight of broad-leaved, narrowleaved, and total weeds at 60 DAS compared with untreated plants. According to results in Table 2, number of broad-leaved, narrow-leaved, and total weeds at 60 DAS were insignificantly affected by thiamine treatments.

The remarkable impact of interaction between weed management and soil salinity on broad-leaved, narrowleaved, and total weeds at 60 DAS as presented in Fig. 1. In this regard, application of oxadiargyl gave the lowest values of broad-leaved and total weeds under salinity level $4.51 \mathrm{dS} \mathrm{m}^{-1}$. While, application of two hand hoeing under salinity level $4.51 \mathrm{dS} \mathrm{m}^{-1}$ achieved the highest decreases in dry weight of narrow-leaved weeds.

Regarding to the interaction between weed control treatments and thiamine application, Fig. 2 shows that foliar spraying of water (untreated thiamine) produced the lowest values of dry weight of total weeds when oxadiargyl treatment was applied. In contrast, the highest total dry weight of faba bean weeds was recorded with unweeded treatment with $100 \mathrm{mg} / \mathrm{l}$ thiamine treatment.

\section{Changes in faba bean growth}

The effect of soil salinity on faba bean growth is presented in Table 3. Soil salinity affect adversely and significantly on faba bean growth. S3 (4.51 dS m $\left.{ }^{-1}\right)$ salinity level caused the highest significant decreases in plant height, shoot dry weight, LAI, and SPAD value. Visversa, planting in soil salinity level $1.37 \mathrm{dS} \mathrm{m}^{-1}$ gave the highest values of aforementioned characters. Weed control treatments significantly increased all the previous mentioned parameters. Two hand hoeing gave the maximum values of aforementioned characters. In contrast, unweeded treatment produced the least values of faba bean characters under study. Regarding thiamine application, it was noted that foliar treatment of faba bean with different concentrations of thiamine increased significantly and gradually the above-mentioned parameters as compared with control plants (Table 3). Further, $100 \mathrm{mg} / \mathrm{l}$ thiamine was the most effective treatments as it caused the highest significant increases in all the abovementioned parameters relative to control plants (Table 3).

With respect to the effect of interaction between weed control treatments and different salinity levels, data clearly show that different weed control methods affect significantly on leaf area index LAI as presented in Fig. 3. Two hand hoeing caused the highest increases in leaf area index (LAI) of faba bean grown under different salinity levels compared with unweeded treatments.

Analysis of data revealed that the combined effect of salinity levels and thiamine concentrations significantly affect on leaf area index (Fig. 4). Different concentrations of thiamine vitamin $(0,50,75$, or $100 \mathrm{mg} / \mathrm{l})$ caused significant increases in LAI with different salinity levels as compared with their corresponding untreated controls. Maximum increase in leaf area index was obtained at1.31 dS m$~^{-1}$ salinity level with application of $100 \mathrm{mg} / \mathrm{l}$ thiamine. While at $4.51 \mathrm{dS} \mathrm{m}^{-1}$, salinity level gave the minimum values of leaf area index without thiamine application.

Results in Fig. 5 show the significant effect of the interaction between weed control and thiamine levels. Application of thiamine with different concentrations increased significantly on LAI as compared with untreated control. Further, $100 \mathrm{mg} / \mathrm{l}$ concentration significantly increased leaf area index with hand hoeing treatment. While the lowest leaf area index was recorded with unweeded treatment without thiamine application.

\section{Changes in carbohydrate constitutes, free amino acids, and proline}

Results of changes in carbohydrate constituents, free amino acids, and proline of faba bean shoot are presented in Table 4. Data clearly show that carbohydrate constituents (total carbohydrates, polysaccharides, and total soluble sugars), free amino acids, and proline significantly differ in response to different salinity levels $\mathrm{dS} \mathrm{m}^{-1}$. Increasing salinity levels from 1.3 to 3.31 to $4.51 \mathrm{dS} \mathrm{m}^{-1}$ caused significant and gradual increases in 

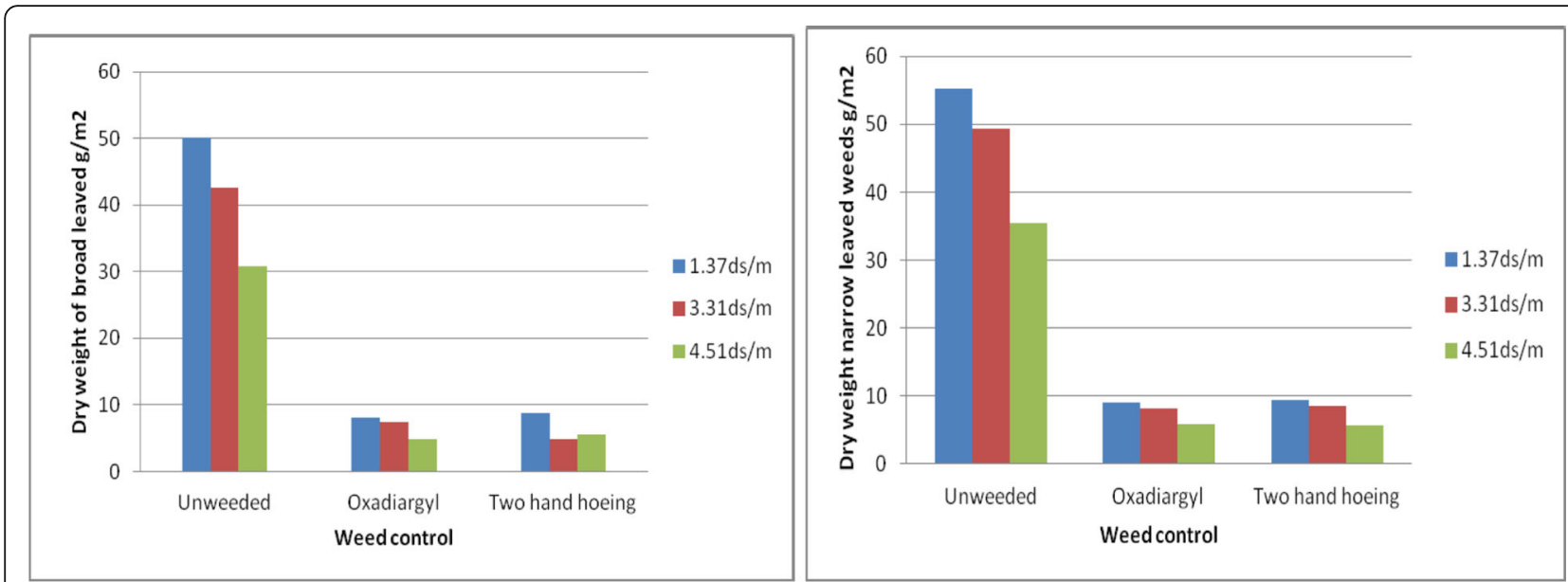

LSD at $5 \%: 3.11$

LSD at 5\%:3.32

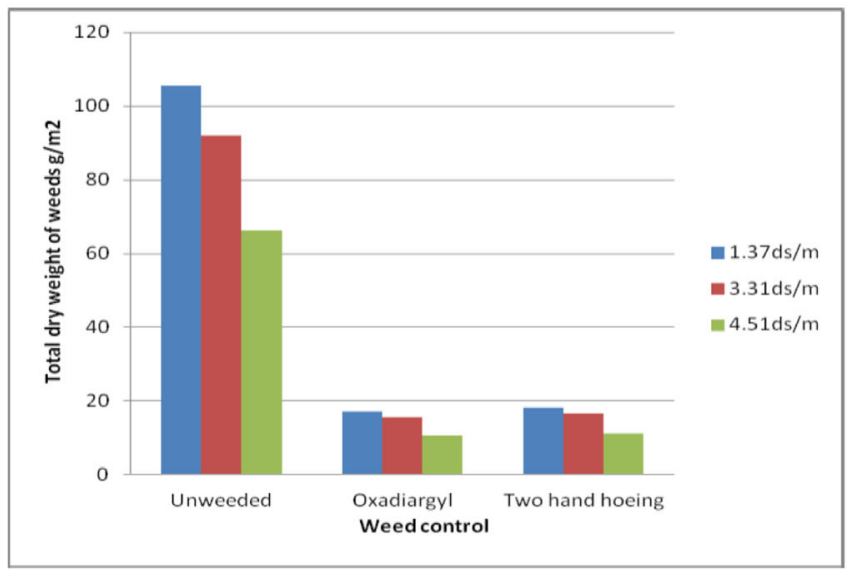

LSD at $5 \%: 3.48$

Fig. 1 Effect of the interaction between weed control and salinity levels on faba bean weeds dry weight $\left(\mathrm{g} / \mathrm{m}^{2}\right)$ at 60 days from sowing (combined analysis of two seasons)

total soluble sugar, free amino acids, and proline contents of faba bean plants; meanwhile, significant gradual decreases in polysaccharides and total carbohydrates contents of faba shoots.

According to results in Table 4, polysaccharides, total carbohydrates, total soluble sugar, free amino acids, and proline were insignificantly affected by weed control treatments.

The resulted data of foliar treatment of thiamine different concentrations (Table 4) show that all concentration of thiamine $(50,75$, and $100 \mathrm{mg} / \mathrm{l})$ caused marked enhancement in polysaccharides, total carbohydrates, free amino acids, and proline as compared with untreated control. Then, $75 \mathrm{mg} / \mathrm{l}$ of thiamine caused the highest increases in the above mentioned characters compared with other treatments.

The interaction between salinity levels and thiamine levels was significantly affected by free amino acids

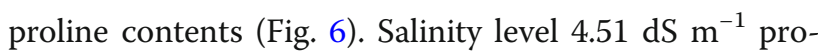
duced the highest content of free amino acids and proline with thiamine at $75 \mathrm{mg} / \mathrm{l}$ foliar treatment. Moreover, the minimal values of free amino acids and proline were

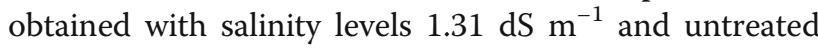
plots with thiamine.

\section{Changes in yield, yield attributes, and seed chemical constitutes of faba bean seeds}

Seed yield, yield attributes (number of pods plant ${ }^{-1}$, pods dry weight plant $^{-1}$, number of seeds plant ${ }^{-1}$, weight of seeds plant ${ }^{-1}$, and 100 -seeds weight) and total carbohydrates percentages were reduced significantly by increasing salinity levels from 1.37 to $4.51 \mathrm{dS} \mathrm{m}^{-1}$ (Table 5) as compared with $1.37 \mathrm{dS} \mathrm{m}^{-1}$. Meanwhile, increasing salinity levels up to $4.51 \mathrm{dS} \mathrm{m^{-1 }}$ increased protein percentage. 


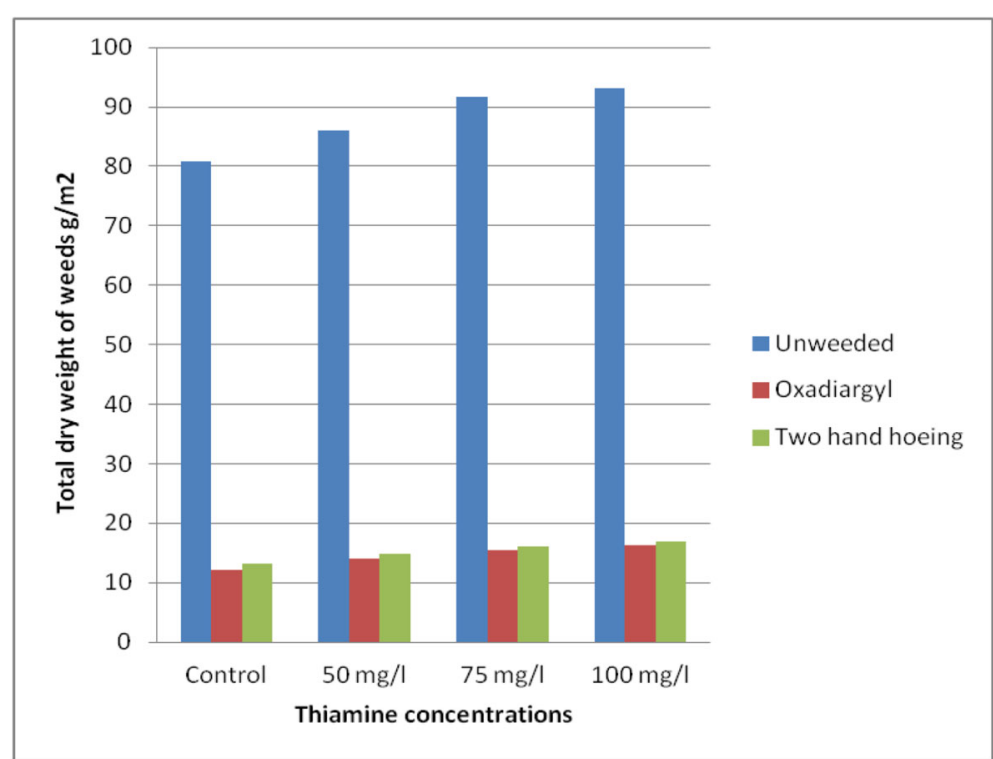

LSD at $5 \%: 4.52$

Fig. 2 Effect of the interaction between thiamine levels and weed control on total dry weight of weeds $\left(\mathrm{g} / \mathrm{m}^{2}\right)$ faba bean at 60 days from sowing (combined analysis of two seasons)

Significant differences were observed in function of weed management practices in yield and its attributes as well as chemical constitutes of seeds (Table 5). Two hand hoeing treatments provided the maximum values in number of pods plant ${ }^{-1}$, pods dry weight plant $^{-1}$, number of seeds plant $^{-1}$, weight of seeds plant $^{-1}, 100$ seeds weight, seed yield, total carbohydrates, and protein percentage compared to the unweeded treatment. The increases in seed yield resulting from two hand hoeing amounted to $57.8 \%$. In addition, oxadiargyl was the best

Table 3 Effect of weed control and thiamine levels on growth and physiological characters of faba bean under salinity condition after 60 and 90 days from sowing (combined analysis of two seasons)

\begin{tabular}{|c|c|c|c|c|c|c|c|c|}
\hline \multirow[t]{2}{*}{ Treatments } & \multicolumn{4}{|l|}{ At 60 from sowing } & \multicolumn{4}{|l|}{ At 90 from sowing } \\
\hline & Plant height (cm) & Shoot dry weight (g) & LAl & $\begin{array}{l}\text { SPAD } \\
\text { value }\end{array}$ & Plant height (cm) & Shoot dry weight (g) & LAl & $\overline{\text { SPAD value }}$ \\
\hline \multicolumn{9}{|l|}{ Salinity levels ( $\left.\mathrm{dS} \mathrm{m}^{-1}\right)$} \\
\hline 1.37 & 85.70 & 30.14 & 4.77 & 39.20 & 123.80 & 37.70 & 7.52 & 39.90 \\
\hline 3.31 & 81.00 & 26.81 & 4.00 & 35.90 & 117.00 & 31.10 & 5.16 & 36.50 \\
\hline 4.51 & 70.60 & 21.71 & 2.97 & 33.50 & 100.80 & 28.50 & 4.46 & 33.10 \\
\hline LSD 0.05 & 4.21 & 2.23 & 0.34 & 2.16 & 4.87 & 2.48 & 0.39 & 2.11 \\
\hline \multicolumn{9}{|l|}{ Weed control: } \\
\hline Unweeded & 76.90 & 21.23 & 3.50 & 34.10 & 108.30 & 27.10 & 5.00 & 35.00 \\
\hline Oxadiargyl & 79.80 & 28.17 & 3.98 & 36.70 & 115.80 & 34.60 & 5.92 & 37.00 \\
\hline Two hand hoeing & 8150 & 29.38 & 4.24 & 36.80 & 117.80 & 35.50 & 6.21 & 37.40 \\
\hline LSD 0.05 & 2.80 & 1.82 & 0.45 & 1.21 & 4.50 & 3.21 & 0.27 & 1.13 \\
\hline \multicolumn{9}{|l|}{ Thiamine levels (mg/l) } \\
\hline Control & 71.50 & 19.80 & 3.50 & 34.50 & 102.2 & 23.60 & 5.28 & 35.00 \\
\hline 50 & 76.60 & 25.40 & 3.96 & 35.40 & 110.9 & 31.40 & 5.63 & 36.60 \\
\hline 75 & 83.00 & 28.00 & 4.20 & 36.60 & 120.7 & 35.00 & 5.88 & 37.10 \\
\hline 100 & 85.00 & 31.70 & 4.04 & 37.50 & 121.8 & 39.60 & 6.05 & 37.80 \\
\hline LSD 0.05 & 1.80 & 2.14 & 0.18 & 0.75 & 3.39 & 3.67 & 0.14 & 0.56 \\
\hline
\end{tabular}




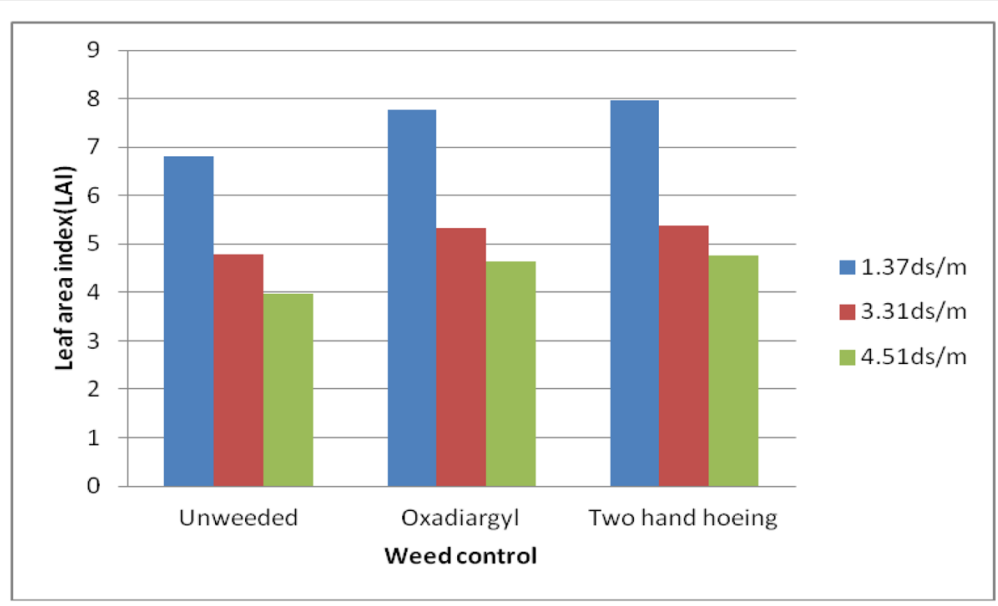

LSD at 5\%:0.34

Fig. 3 Effect of the interaction between salinity levels and weed control on LAl of faba bean at 90 days from sowing (combined analysis of two seasons)

treatment to promote seed yield exceeding the unweeded check by $50.0 \%$, respectively.

Concerning to the effect of foliar application of thiamine on number of pods plant ${ }^{-1}$, pods dry weight plant ${ }^{-1}$, number of seeds plant ${ }^{-1}$, weight of seeds plant $^{-1}, 100$-seeds weight, seed yield ton/ha total carbohydrates $\%$, and protein $\%$ (Table 5). The resulted data showed that all concentration of thiamine improve yield, its attributes, and chemical composition of the yielded seeds as compared with those untreated plants (control). The presented data revealed that foliar application of thiamine at rate of $100 \mathrm{mg} / \mathrm{l} \mathrm{re}-$ sulted the highest seed yield (35.3\%) compared with untreated plots.
Figure 7 show the effect of interaction of different salinity levels and weed control treatments on seed yield (ton/ha) and seed protein \% of faba bean. Different weed control treatments increased significant seed yield and seeds protein \% as compared with the corresponding unweeded treatments at different salinity levels. The highest seed yield and protein percentage (Fig. 7) was obtained when faba bean sowing at a level of salinity $1.31 \mathrm{dS} \mathrm{m}^{-1}$ with hand hoeing treatment followed by the same level combined with oxadiargyl herbicides without significant difference among these treatments. On the other hand, the lowest seed yield and protein percentage was recorded from the unweeded treatment

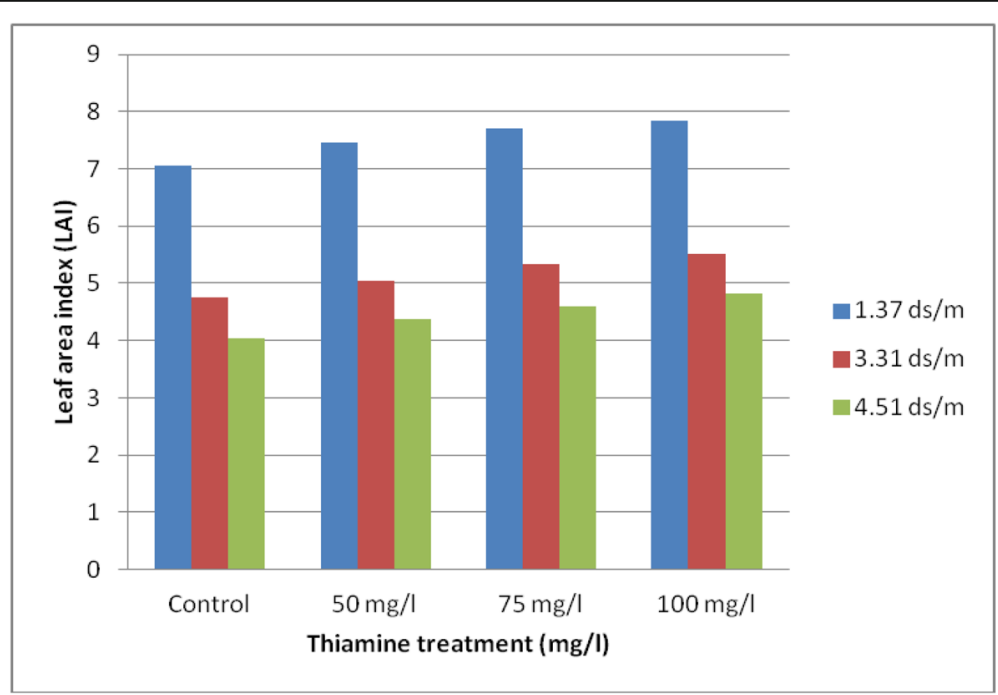

LSD at 5\%: 0.46

Fig. 4 Effect of the interaction between salinity levels and thiamine levels on LAl of faba bean at 90 days from sowing (combined analysis of two seasons) 


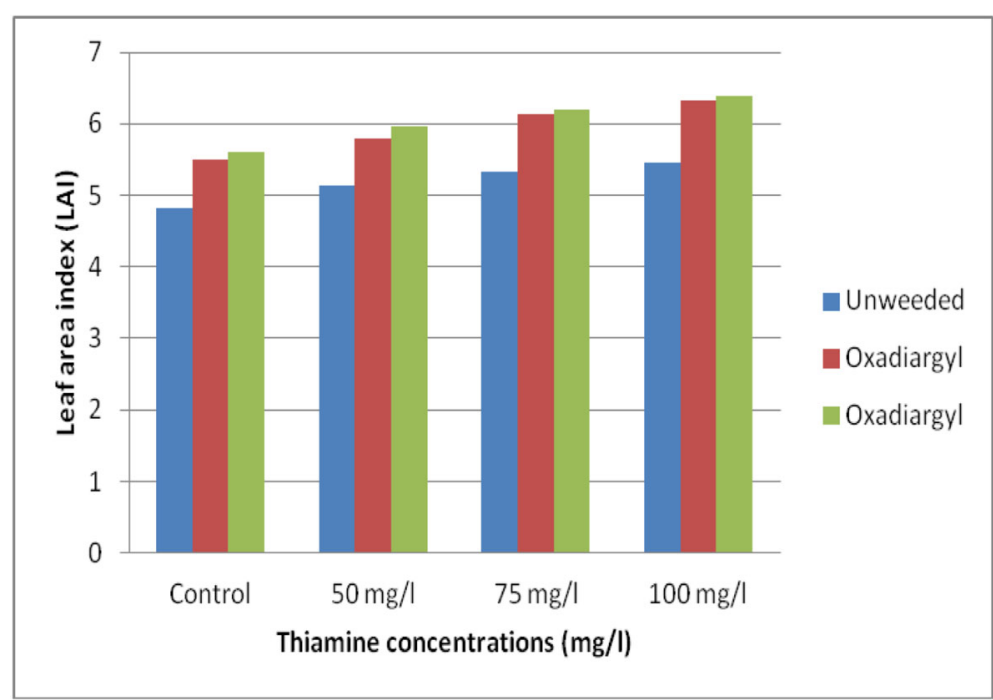

LSD at 5\%: 0.42

Fig. 5 Effect of the interaction between thiamine levels and weed control on LAl of faba bean at 90 days from sowing (combined analysis of two seasons)

with faba bean sowing at a level of salinity $4.51 \mathrm{dS} \mathrm{m}^{-1}$.

With respect to the interaction effect between weed control treatments and different thiamine levels on seed yield (ton/ha) and seed protein\% of faba bean plant data are presented in Fig. 8. Different weed control treatment and or thiamine foliar treatment with different concentrations increased significantly seed yield and seed protein \% as compared with their corresponding controls. Application of thiamine at the rate of $100 \mathrm{mg} / \mathrm{l} \mathrm{sig-}$ nificantly increased seed yield and protein percentage with hand hoeing treatment. While the lowest seed yield and protein percentage was recorded with unweeded treatment without thiamine application.

Analysis of data revealed that the combined effect of salinity levels and thiamine with different concentrations

Table 4 Effect of weed control and thiamine treatments on carbohydrates constituents (mg/g dry wt), free amino acids, and proline ( $\mathrm{mg} / 100 \mathrm{~g}$ dry wt) contents of faba bean shoot under salinity condition after 60 days from sowing

\begin{tabular}{|c|c|c|c|c|c|}
\hline Treatments & Total carbohydrates & Polysaccharides & TSS & Free amino acids & Proline \\
\hline \multicolumn{6}{|l|}{ Salinity levels $\left(\mathrm{dS} \mathrm{m}^{-1}\right)$} \\
\hline 1.37 & 259.46 & 231.21 & 25.26 & 158.14 & 31.33 \\
\hline 3.31 & 257.08 & 218.86 & 38.22 & 170.92 & 44.10 \\
\hline 4.51 & 250.24 & 202.87 & 50.37 & 180.21 & 53.40 \\
\hline LSD 0.05 & 1.56 & 5.21 & 4.86 & 5.12 & 3.23 \\
\hline \multicolumn{6}{|l|}{ Weed control } \\
\hline Unweeded & 252.25 & 212.42 & 34.84 & 168.99 & 42.18 \\
\hline Oxadiargyl & 256.97 & 221.21 & 39.15 & 170.90 & 44.07 \\
\hline Two hand hoeing & 257.56 & 219.69 & 39.87 & 169.39 & 42.57 \\
\hline LSD 0.05 & NS & NS & NS & NS & NS \\
\hline \multicolumn{6}{|l|}{ Thiamine levels (mg/l) } \\
\hline Control & 248.73 & 211.82 & 36.91 & 165.11 & 38.30 \\
\hline 50 & 254.99 & 217.15 & 37.84 & 169.27 & 42.45 \\
\hline 75 & 261.52 & 222.74 & 38.78 & 173.45 & 46.64 \\
\hline 100 & 257.13 & 218.87 & 38.26 & 171.21 & 44.40 \\
\hline LSD 0.05 & 2.14 & 1.11 & 0.45 & 1.04 & 1.56 \\
\hline
\end{tabular}




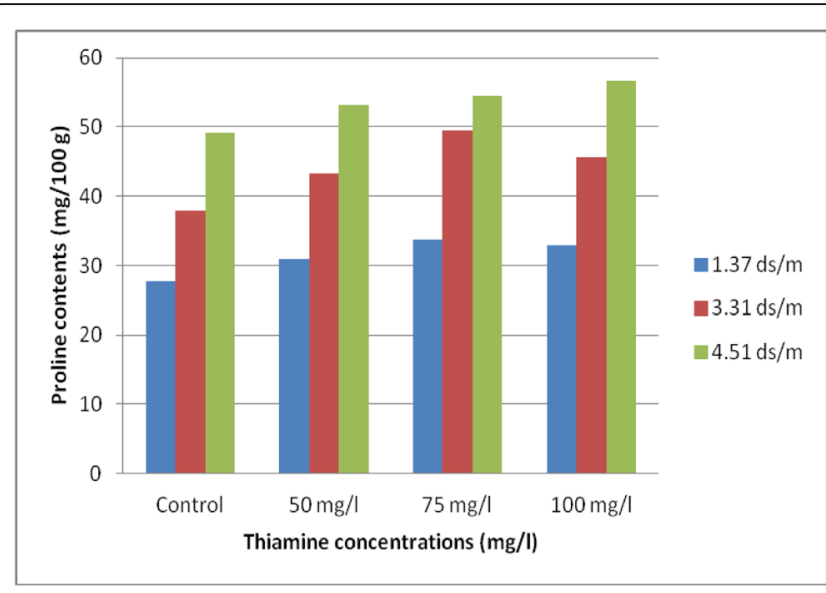

LSD at 5\%: 1.56

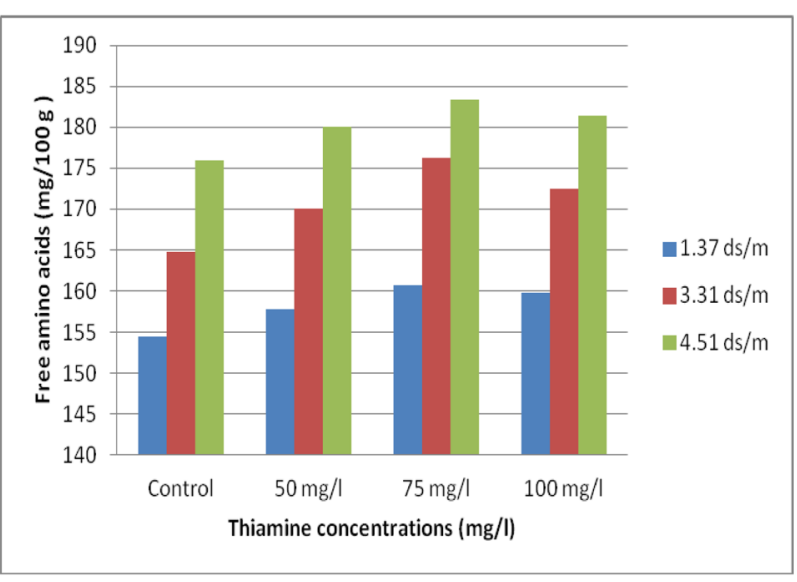

LSD at 5\%: 3.20

Fig. 6 Effect of the interaction between salinity levels and thiamine levels on proline and free amino acids (mg/100 g) contents of faba bean shoot at 60 days from sowing

on seed yield (ton/ha) and seed protein percentage are presented in Fig. 9. Different concentrations of thiamine increased significantly seed yield and protein \% as compared with their corresponding controls at each salinity levels. Maximum increases of seed yield and protein percentage were obtained with foliar treatment of thiamine $100 \mathrm{mg} / \mathrm{l}$ at different salinity levels.

Finally, it could be concluded that thiamine foliar treatment with different concentrations could alleviate the harmful effects of saline soil with different weed control treatment. Further, $100 \mathrm{mg} / \mathrm{l}$ was the most effective treatment with two hand hoeing for enhancing yield and its attributes. Results also indicated that osmoprotectants as total soluble sugars, free amino, and proline works to increase faba bean plants ability to withstand salinity stress. Also, no significant differences between application of two hand hoeing and oxadiargyl treatments on weeds and faba bean characters.

Table 5 Effect of Effect of weed control and thiamine levels on yield, yield attributes, and chemical composition of faba bean seeds under salinity condition (combined analysis of two seasons)

\begin{tabular}{|c|c|c|c|c|c|c|c|c|}
\hline \multirow[t]{2}{*}{ Treatments } & \multicolumn{6}{|c|}{ Yield and yield attributes } & \multicolumn{2}{|c|}{ Chemical composition } \\
\hline & $\begin{array}{l}\text { Pods no/ } \\
\text { plant }\end{array}$ & $\begin{array}{l}\text { Pods weight/ } \\
\text { plant }\end{array}$ & $\begin{array}{l}\text { No of seeds/ } \\
\text { plant }\end{array}$ & $\begin{array}{l}\text { Seeds weight/ } \\
\text { plant }\end{array}$ & $\begin{array}{l}\text { 100-seed } \\
\text { weight }\end{array}$ & $\begin{array}{l}\text { Seed yield } \\
\text { ton/ha }\end{array}$ & $\begin{array}{l}\text { Total } \\
\text { carbohydrates \% }\end{array}$ & $\begin{array}{l}\text { Protein } \\
\%\end{array}$ \\
\hline \multicolumn{9}{|c|}{ Salinity levels (dS $\left.\mathrm{m}^{-1}\right)$} \\
\hline 1.37 & 24.17 & 182.1 & 66.17 & 38.75 & 52.42 & 5.29 & 53.68 & 21.76 \\
\hline 3.31 & 18.92 & 161.3 & 58.33 & 35.58 & 46.33 & 4.57 & 53.65 & 22.90 \\
\hline 4.51 & 12.67 & 140.4 & 49.50 & 22.92 & 38.17 & 3.23 & 52.65 & 23.54 \\
\hline LSD 0.05 & 2.14 & 5.45 & 3.71 & 2.13 & 4.12 & 0.45 & 3.52 & 0.36 \\
\hline \multicolumn{9}{|l|}{ Weed control } \\
\hline Unweeded & 11.58 & 130.8 & 51.17 & 28.17 & 43.33 & 3.20 & 53.65 & 21.80 \\
\hline Oxadiargyl & 19.92 & 168.3 & 60.25 & 33.42 & 45.58 & 4.80 & 54.95 & 23.01 \\
\hline $\begin{array}{l}\text { Two hand } \\
\text { hoeing }\end{array}$ & 20.58 & 184.2 & 62.42 & 35.67 & 48.00 & 5.05 & 55.65 & 23.42 \\
\hline LSD 0.05 & 2.22 & 4.99 & 2.54 & 1.16 & 2.15 & 0.45 & 3.45 & 0.45 \\
\hline \multicolumn{9}{|c|}{ Thiamine levels (mg/l) } \\
\hline Control & 14.77 & 131.7 & 51.67 & 28.11 & 40.56 & 3.63 & 53.91 & 21.57 \\
\hline 50 & 18.11 & 157.2 & 56.33 & 30.78 & 44.11 & 4.14 & 54.65 & 22.42 \\
\hline 75 & 20.56 & 171.7 & 59.11 & 34.11 & 47.55 & 4.64 & 55.95 & 23.32 \\
\hline 100 & 20.89 & 181.1 & 64.11 & 36.67 & 50.33 & 4.91 & 54.95 & 23.66 \\
\hline LSD 0.05 & 1.56 & 4.78 & 2.62 & 2.11 & 2.14 & 0.34 & 3.65 & 0.51 \\
\hline
\end{tabular}




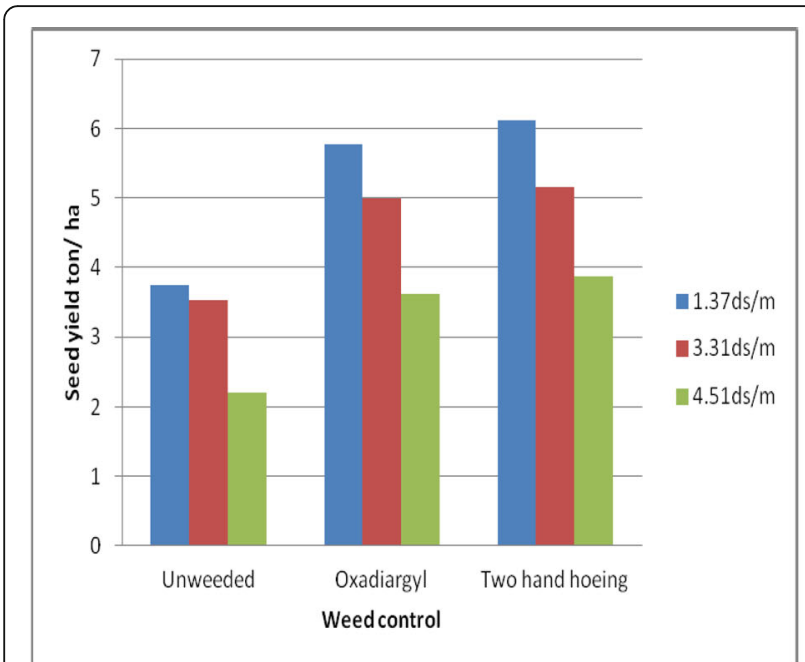

LSD at 5\%: 0.29

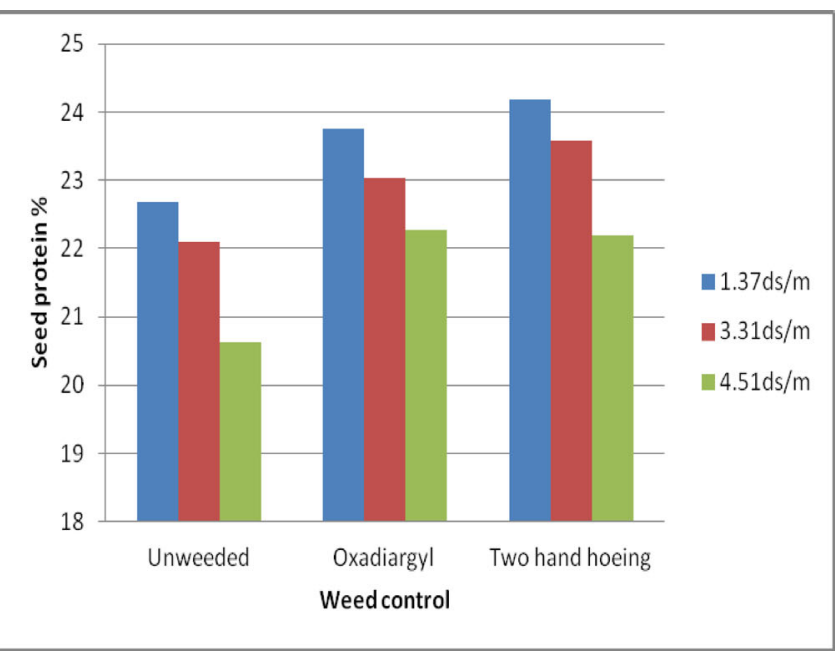

LSD at 5\%: 0.74

Fig. 7 Effect of the interaction between salinity levels and weed control on seed yield ton/ha and seed protein\% (combined analysis of two seasons)

\section{Discussion}

Results in Table 2 clearly indicate that treatment of oxadiargyl was more efficient and exerted the highest reduction in dry weight of broad-leaved, narrow-leaved, and total weeds. Oxadiargyl was more efficient and exerted the highest reduction in number of broad-leaved. While two hand hoeing gave the lowest values of number of narrow-leaved and total weeds. Several reports have confirmed that hoeing twice is the most effective weed control practice for reducing weed dry matter accumulation in faba bean fields. Meanwhile, oxadiargyl was more effective in controlling total weeds and resulted in the highest reduction of dry matter when compared with unweeded treatments. This reduction of weed dry weight may be due to the inhibition effect of herbicide treatments on growth and development of weeds. No significant differences between application of two hand hoeing and oxadiargyl treatments on growth of weeds. These results are in general agreement with those recorded by Soliman et al. (2015), Dawood et al. (2016), and ElMetwally and Dawood (2016). With respect to the positive effect of thiamine treatments on weed faba bean have been confirmed by Dawood et al. (2016) and ElMetwally (2016).

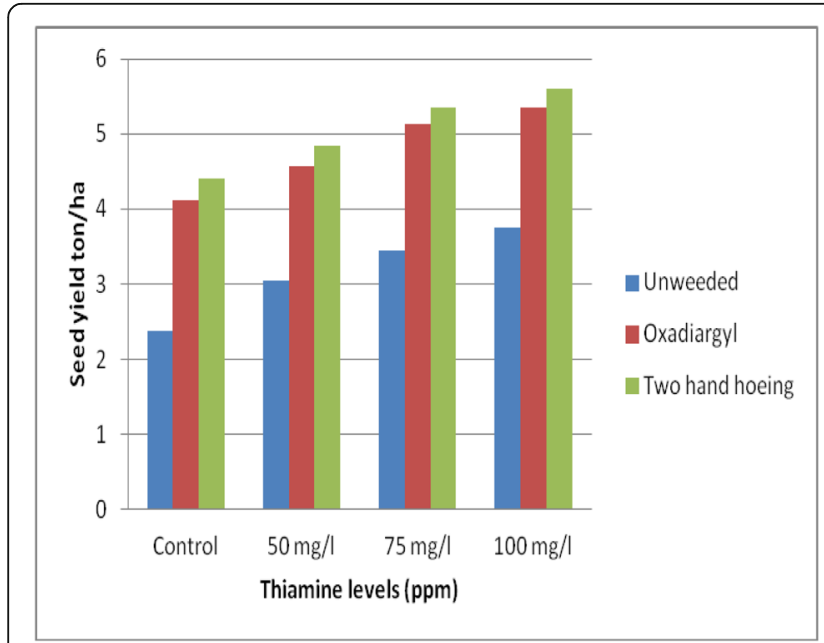

LSD at 5\%: 0.33

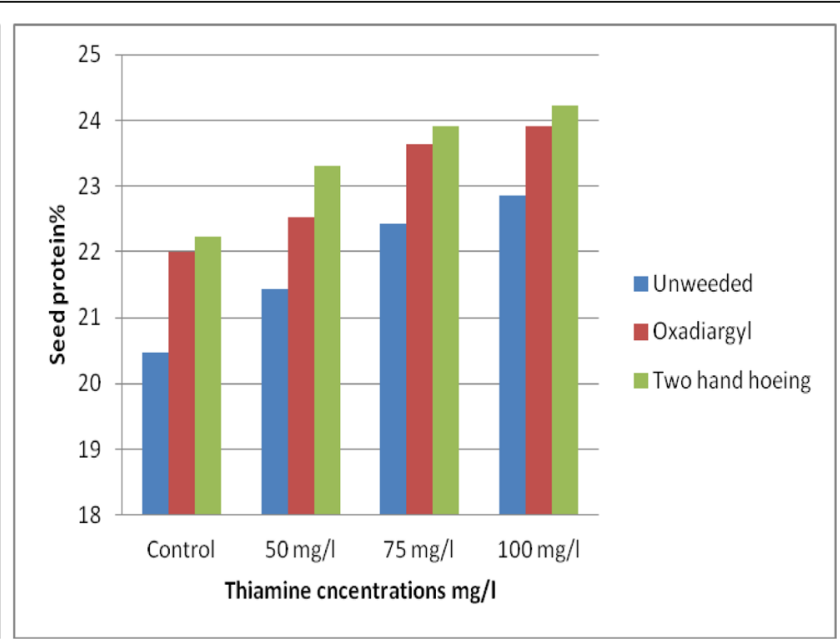

LSD at 5\%: 0.41

Fig. 8 Effect of the interaction between thiamine levels and weed control on seed yield ton/ha and seed protein percentages (combined analysis of two seasons) 


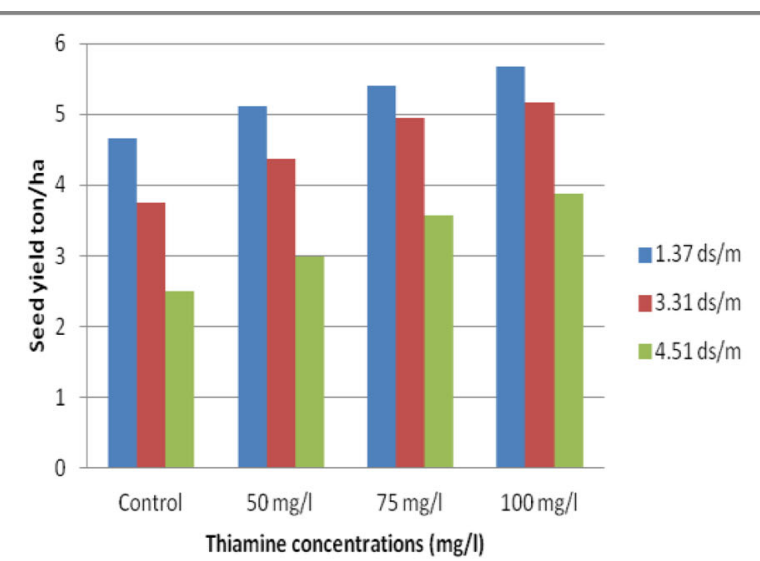

LSD at 5\%: 0.36

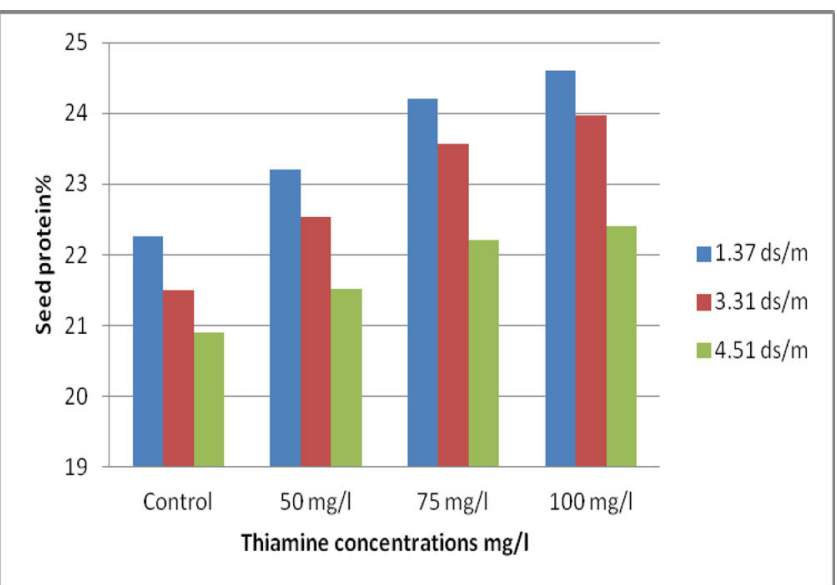

LSD at 5\%: 0.38

Fig. 9 Effect of the interaction between salinity levels and thiamine levels on seed yield ton/ha and seed protein\% (combined analysis of two seasons)

Soil salinity decreased significantly faba bean growth. S3 $\left(4.51 \mathrm{~d} \mathrm{~m}^{-1}\right)$ salinity level caused the highest significant decreases (Table 3). Farouk et al. (2011) stated that such reduction in growth characters could be ascribed to the reducing effect of salinity on cell division and cell enlargement, increase energy required for absorption of minerals and water, accumulation of some poisonous compounds in plant cells, high respiration rate, inhibition of protein turnover, and nucleic acid synthesis. Our results of reduced salinity stress effect on growth parameters of faba bean plant are in harmony with Bakhoum and Sadak (2016), Elewa et al. (2017), Sadak (2019), and Dawood et al. (2019); they stated that growth parameters of sunflower, quinoa, wheat, and sunflower plants decreased with salinity and drought stress and attributed these reductions to the metabolic disorders induced by stress and generation of excess ROS. Also, the decrease in shoot height in response to salinity might be due to the decrease in cell elongation, cell turgor, cell volume, and eventually cell growth (Banon et al. 2006). In addition, these reductions in growth parameters might be referred to the effect of high osmotic stress and ion toxicity (Hasanuzzaman et al. 2013) or due to altered cell wall structure induced by stress (Sweet et al. 1990). In addition, the decreases in LAI, resulting from the reduction in supply of carbon assimilate due to decreasing the net photosynthetic rate and biomass accumulation. As well as the decrease in chlorophyll content might be related to the increase in activity of chlorophyll degrading enzyme, chlorophyllase, and the destruction of chloroplast structure and the instability of pigment protein complexes (Verma et al. 2012). Semida et al. (2014) confirmed this reduction on all growth traits, and reported a decrease on leaf area and chlorophyll concentration due to salinity. Weed control treatments significantly increased all the previous mentioned parameters. Two hand hoeing gave the maximum values of aforementioned characters. These findings may be due to the role of hand hoeing in controlling weeds. Consequently, decrease in the competition between faba bean and different weeds thus light, water, and nutrients become available to faba bean growth. Results also indicate that no significant differences between application of two hand hoeing and oxadiargyl treatments on faba bean growth. These findings might be due to the role of hand hoeing or oxadiargyl treatments in controlling weeds. By decreasing the competition between faba bean and weeds thus light, water, and nutrients become available to faba bean growth. Regarding thiamine application, it was noted that foliar treatment of faba bean with different concentrations of thiamine increased significantly and gradually the above-mentioned parameters as compared with control plants (Table 3). Thiamine is a strong antioxidant and plays an important role in different physiological processes including plant growth and development. It prevents lipid peroxidation and protects chloroplast membranes from photo-oxidation and assists the transport of electrons in photosystem-II Farouk et al. (2011). El-Awadi et al. (2016) and Khafagy et al. (2016) found that thiamine significantly increased growth parameters of Lupine plant and barley plant. Thiamine as a vitamin and its main role as a functional coenzyme thiamine pyrophosphate which play an important role in the balance of carbon metabolism of crops. In addition, the obtained results of improving faba bean plant growth by thiamine foliar treatment might be due to its role in enhancing cell division and endogenous phytohormones in plant. As well as the enhancement of thiamine 
vitamin might be due to the main role of vitamins as coenzymes, alleviation of the harmful effects of stress in addition to the role of vitamins in different biochemical processes of the plant.

Data in Table 4 clearly show that carbohydrate constituents, free amino acids, and proline significantly differ in response to different salinity levels $\mathrm{dS} \mathrm{m}^{-1}$. Increasing salinity levels from 1.3 to 3.31 to $4.51 \mathrm{dS} \mathrm{m}^{-1}$ caused significant and gradual increases in total soluble sugar, free amino acids, and proline contents of faba bean plants; meanwhile, significant gradual decreases in polysaccharides and total carbohydrates contents of faba shoots. These decreases in total carbohydrates of salinity stressed faba bean plant concomitantly with the reduction in leaf photosynthetic pigments (SAPD, Table 3) led to the conclusion that salinity may inhibit photosynthetic activity and/or increased partial utilization of carbohydrates into other metabolic pathways (Hassanein et al. 2009). These results of stress are in agreement with those obtained by El-Bassiouny and Sadak (2015) on flax cultivars, El-Bassiouny et al. (2017) on sunflower plant, and Sadak et al. (2019) on quinoa plant. De Ridder and Salvucci (2007) reported that the reduction of total carbohydrates under salinity stress is probably due to higher sensitivity of photosystem II, decrease of $\mathrm{CO}_{2}$ in intercellular spaces of stomata, reduction in photochemical quantum efficiency of $\mathrm{CO}_{2}$ uptake, low level of $\mathrm{O}_{2}$ evolution, and low level of 3-phosphoglycerate. These circumstances may lead to the reduction in carbon allocation to new leaves and furthermore to potential photosynthetic capacity resulted in reduction of photon yield of $\mathrm{CO}_{2}$ assimilation and consequently minimize starch synthesis under salinity stress. In this connection, (Patakas et al. 2002) stated that under salinity stress, plant growth reduced and accumulates solutes in cells to preserve the volume and larger against dehydration. Also, soluble sugars are the major category of compatible organic solutes which play an important role in relieving salinity stress through giving some salinity tolerance of plant cells or by osmotic adjustment (El-Bassiouny et al. 2017). As well as these increases in total soluble sugars of faba bean plants may indicate more stimulation in enzymes of sugar hydrolysis. In addition, Srivastava et al. (1995) stated that accumulations of TSS play a key role in alleviating salinity stress either via osmotic adjustment or by conferring desiccation resistance to plant cells. Concerning total carbohydrates and polysaccharides, the decreased contents of chlorophyll synthesis in Table 3 in response to irrigation of saline water might be the results of decreased the biosynthesis of total carbohydrates and polysaccharides contents of faba bean plant. With respect to free amino acids and proline, proline accumulation is one of the most frequently reported modifications induced by water and salt stress in plants and is often considered to be involved in stress resistance mechanisms. Its possible roles have been attributed for stabilizing the structure of macromolecules and organelles through stabilizing proteins and membranes against denaturation effect of high concentrations of salts and other harmful solutes (Munns 2002). Salt stress induced decreases in total $\mathrm{N}$ while increased accumulation of proline and free amino acids with increasing salinity level. These findings are in good agreement with those obtained by Amirjani (2010), Sadak et al. (2010), Taie et al. (2013), and El-Bassiouny et al. (2017). According to results in Table 4, polysaccharides, total carbohydrates, total soluble sugar, free amino acids, and proline were insignificantly affected by weed control treatments.

The resulted data of foliar treatment of thiamine different concentrations (Table 4) show that all concentration of thiamine caused marked enhancement in polysaccharides, total carbohydrates, free amino acids, and proline as compared with untreated control. The increments in soluble and total carbohydrates under the effect of thiamine treatments are similar to those obtained by Rady et al. (2011), El-Bassiouny and Sadak (2015), Sadak (2016), and Khafagy et al. (2017). They mentioned that vitamins application stimulated the accumulation of total soluble sugars in salt-affected sunflower cultivars, flax, pea, and lupine plants, respectively under stress conditions, either via increasing endogenous levels of certain phytohormones or by acting as activators of carbohydrates synthesis. Further, these increments in carbohydrate contents probably might be attributed to the protective effects of thiamine on photosynthetic systems. It could be suggested that salt tolerance was manifested via activated proline synthesis and hydrolysis of protein into free amino acids to act as osmoprotectants in the different organs of the plant. Under salinity stress, increased proline concentration lowers the generation of free radicals and thus reduces lipid peroxidation as well acting as a mediator of osmotic adjustment and/or stabilizer of subcellular structures. The interaction between salinity levels and thiamine levels significantly affected by free amino acids proline contents (Fig. 6). Salinity level $4.51 \mathrm{dS} \mathrm{m}^{-1}$ produced the highest content of free amino acids and proline with thiamine at $75 \mathrm{mg} / \mathrm{l}$ foliar treatment. Moreover, the minimal values of free amino acids and proline were obtained with salinity levels $1.31 \mathrm{dS} \mathrm{m}^{-1}$ and untreated plots with thiamine. Similar results have been reported by Abdelhamid et al. (2013), El-Bassiouny and Sadak (2015), and Sadak (2016) on different plant species.

Seed yield, yield attributes, and total carbohydrates percentages were reduced significantly by increasing salinity levels from 1.37 to $4.51 \mathrm{dS} \mathrm{m}^{-1}$ (Table 5) as com-

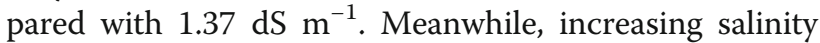
levels up to $4.51 \mathrm{dS} \mathrm{m}^{-1}$ increased protein percentage. 
The observed decreases in seed yield and its attributes in the present work could be attributed to the obtained reduction in LAI (Table 3) which might affect on photosynthetic efficiency of faba bean leaves and hence, carbohydrate contents of plants (Table 4). Similarly, Van Hoorn et al. (2001) mentioned that the reduction in yield of soybean plants under salinity stress was attributed to the decrease in photosynthetic rate, carbohydrate accumulation, nitrogenase activity, and consequently seed yield. In addition, the reduction in the yield could be also attributed to the accumulation of toxic ions, impaired uptake of essential nutrients and/or damage in cellular organelles as reported by Torres-Schumann et al. (1989). Also, high salinity levels significantly increased protein percentage compared to low salinity levels. Similar results have been reported by Dawood et al. (2016) and Mohsen et al. (2018). Significant differences were observed in function of weed management practices in yield and its attributes as well as chemical constitutes of seeds (Table 5). The superiority of these treatments in producing high seed yield might be due to their high efficiency in controlling broad spectrum of weeds without damaging faba bean plants, thus reduce weed competitive capacity, leading to increase in seed yield. Also, these increases due to application of hand hoeing over the weedy check was reported in number of pods per plant (El-Metwally 2016), in pod dry weight per plant (El-Metwally and Dawood 2016) and seed yield per ha El-Metwally et al. 2017.

The resulted data (Table 5) showed that all concentration of thiamine improve yield, its attributes, and chemical composition of the yielded seeds as compared with those untreated plants (control). El-Awadi et al. (2016) and Aminifard et al. (2018) stated that thiamine treatment caused significant increases in seed yield and yield components, oil and protein contents in Lupine plant and fenugreek plants. Thiamine is necessary for dividing meristematic stem cells and organ initial cells (Martinis et al. 2016). Moreover, the accumulation of some osmoregulators, such as soluble sugars and free amino acids, may increase in response to thiamine application. This phenomenon, by changing the water potential of plants, can increase the turgor pressure, which is needed for cell expansion and thereby plant growth and yield (Sayed and Gadallah 2002). Thiamine are believed to protect chloroplast membranes from photo-oxidation and help to provide an optimal environment for photosynthetic machinery, delaying senescence and increasing photosynthetic products (Collin et al. 2008). Phytoregulator compounds (as thiamine) were suggested to elevate and tolerate the adverse effects of biotic and abiotic stresses on plant growth and yield. Under saline conditions, Rady et al. (2015) reported that foliar application of thiamine on faba bean induced marked increases in photosynthetic pigments as well as yield and yield components. The enhancement role of thiamine on growth parameters, SPAD value (Table 3), soluble and total carbohydrates, proline, and soluble proteins may be reflected by its role in ameliorating the harmful effect of salinity stress on faba bean plants, causing significant increases in carbohydrates and proteins. These results are in good agreements with those reported by Rady et al. (2015) on soybean plant.

\section{Conclusion}

We could conclude that foliar application of thiamine at the rate of $100 \mathrm{mg} / \mathrm{l}$ caused the highest increases in all growth and yield parameters under investigation of faba bean plant. Interaction of $100 \mathrm{mg} / \mathrm{l}$ thiamine treatment and two hand hoeing was the most effective treatment on enhancing faba bean growth, yield, and its attributes under salinity levels. Results also indicated that free amino and proline works to increase faba bean plants ability to withstand salinity stress.

\section{Abbreviations \\ 2HH: Two hand hoeing; DAS: Days after sowing; LAl: Leaves area index; $\mathrm{N}_{2}$ fixation: Nitrogen fixation; NADP: Nicotinamide adenine dinucleotide phosphate; SAPD: Chlorophyll meter; TSS: Total soluble sugars; UW: Unweeded; Vit B: Vitamin B \\ Acknowledgements \\ Not applicable. \\ Funding \\ Not applicable. \\ Availability of data and materials \\ Not applicable. \\ Authors' contributions \\ All authors share in every step of this work and all of them contribute in writing the manuscript. All authors read and approved the final manuscript.}

Ethics approval and consent to participate

Not applicable.

Consent for publication

Not applicable.

\section{Competing interests}

The authors declare that they have no competing interests.

\section{Publisher's Note}

Springer Nature remains neutral with regard to jurisdictional claims in published maps and institutional affiliations.

Received: 28 February 2019 Accepted: 7 June 2019

Published online: 05 July 2019

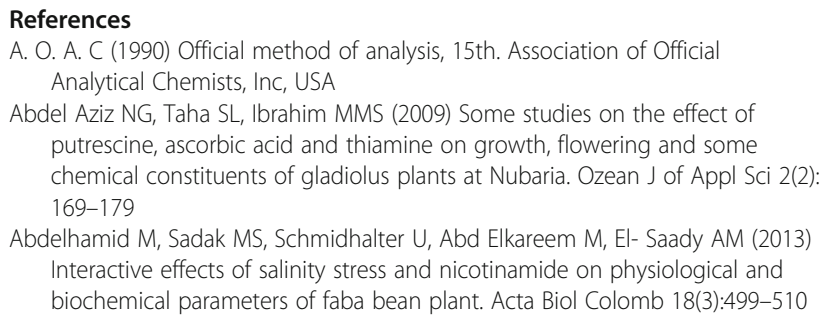
putrescine, ascorbic acid and thiamine on growth, flowering and some chemical constituents of gladiolus plants at Nubaria. Ozean J of Appl Sci 2(2): 169-179

Abdelhamid M, Sadak MS, Schmidhalter U, Abd Elkareem M, El- Saady AM (2013) Interactive effects of salinity stress and nicotinamide on physiological and biochemical parameters of faba bean plant. Acta Biol Colomb 18(3):499-510 
Al-Rawahy SA, Al-Dhuhli HS, Prathapar S, Abdel Rahman H (2011) Mulching material impact on yield, soil moisture and salinity in saline-irrigated sorghum plots. Inter J Agric Res 6(1):75-81

Aminifard MH, Jorkesh A, Fallahi H, Alipoor K (2018) Foliar application of thiamine stimulates the growth and biochemical compounds production of coriander and fenugreek. J Hort Res 26(1):77-85

Amirjani MR (2010) Effect of salinity stress on growth, mineral composition, proline content, antioxidant enzymes of soybean. Plant Physiol 5(6):350-360. https://doi.org/10.3923/ajpp.2010.350.360

Ashraf M (2010) Inducing drought tolerance in plants: some recent advances. Biotechnol Adv 28:169-183

Bakhoum GSH, Sadak MS (2016) Physiological role of glycinebetaine on sunflower (Helianthus annuus L.) plants grown under salinity stress. Int J Chem Tech Res 9(3):158-171

Banon SJ, Ochoa J, Franco JA, Alarcon JJ, Sanchez-Blanco M (2006) Hardening of oleander seedlings by deficit irrigation and low air humidity. Environ Exp Bot 56:36-43

Bates LS, Waldren RP, Teare LD (1973) Rapid determination of free proline under water stress studies. Plant Soil 39:205-207

Bertschinger L, Stadler W (1997) Vitamin E, first results from field trial in Switzerland. Obst Weinbau 133(6):150-151

Bidwell RGS (1979) Plant physiology, 2nd edn. Macmillan Publishing Co., Inc, New York, pp 236-238

Chapman HD, Pratt PE (1978) Methods of Analysis for Soils, Lands, and Waters. Univ. of Calif., Div. Agric. Sci, Berkeley, pp 162-165

Collin VC, Eymery F, Genty B, Rey P, Havau P (2008) Vitamin E is essential for the tolerance of Arabidopsis thaliana to metal-induced oxidative stress. Plant Cell Environ 31:244-257

Dawood MG, El-Awadi ME, Sadak MS, El-Lethy SR (2019) Comparison between the physiological role of carrot root extract and $\beta$-carotene in inducing Helianthus annuus L. drought tolerance. Asian J Biol Sci 12(2):231-241

Dawood MG, El-Metwally IM, Abdelhamid MT (2016) Physiological response of lupine and associated weeds grown at salt-affected soil to a-tocopherol and hoeing treatments. Gesunde Pflanzen 68:117-127

De Ridder BP, Salvucci M (2007) Modulation of Rubiscoactivase gene expression during heat stress in cotton (Gossypium hirsutum L.) involves posttranscriptional mechanisms. Plant Sci 172(2):246-252

Dubois M, Guilles KA, Hamilton JK, Rebers PA, Smith F (1956) Colorimetric method for determination of sugars and related substances. Anal Chem 28 350-356.

El -Metwally IM, Abdelhamid MT (2008) Weed control under integrated nutrient management systems in Faba bean (Vicia faba) production in Egypt. Plant Daninha 26(3):585-594

El-Awadi ME, Abd Elbaky YR, Dawood MG, Shalaby MA, Bakry BA (2016) Enhancement quality and quantity of lupine plant via foliar application of some vitamins under sandy soil conditions. Res J Pharm Biol Chem Sci 7:1012-1024

El-Bassiouny HMS, Abd El-Monem AA, Sadak MS, Badr NM (2017) Amelioration of the adverse effects of salinity stress by using ascorbic acid in sunflower cultivars. Bull NRC 41(2):233-249

El-Bassiouny HMS, Sadak MS (2015) Impact of foliar application of ascorbic acid and a- tocopherol on antioxidant activity and some biochemical aspects of flax cultivars under salinity stress. Acta Biologia Colomb 20(2):209-221

Elewa TA, Sadak MS, Saad AM (2017) Proline treatment improves physiological responses in quinoa plants under drought stress. Biosci Res 14(1):21-33

El-Metwally IM (2016) Efficiency of some weed control treatments and some biostimulants on growth, yield and its components of faba bean and associated weeds. Int J Pharm Tech Res 9(12):165-174

El-Metwally IM, Abido WAE, Tagour RMH (2017) Influence of plant population and weed control treatments on associated weeds, growth, yield and quality of faba bean. J Plant Prod Mansoura Univ 8(10):983-991

El-Metwally IM, Dawood MG (2016) Response of faba bean plants to weed control treatments and foliar spraying of some bio-stimulants under sandy soil condition. Int J Pharm Tech Res 9(12):155-164

El-Metwally IM, Shalby SEM (2007) Bio - remediation of Fluazifop -P- butyl herbicide contaminated soil with special reference to efficacy of some weed control treatments in faba bean plants. Res J Agric Biol Sci 3(3):157-165

Farouk S, Abo-EL-Kheer AM, Sakr MT, Khafagy MA (2011) Osmoregulators or plant growth substances as a growth inducer for pea plants under salinity levels. Int J Agric Plant Prod 2:168-180

Ghassemi F, AJ Jakeman and HA Nix, 1995."Salinisation of land water resources: human causes, extent, management and case studies". UNSW press, Sydney,
Australia and CAB international, Wallingford, UK. Gomez, K. a. and A. A. Gomez, 1984. Statistical procedure for agricultural research. John Wiley and son. New York

Gomez AK, and Gomez AA, (1984). Statistical procedures for Agricultural Research.2nd ed. John Wiley and Sons, New York.

Hasanuzzaman M, Nahar K, Fujita M (2013) Plant response to salt stress and role of exogenous protectants to mitigate salt-induced damages. In: Ahmad P, Azooz MM, Prasad MNV (eds) Ecophysiology and Responses of Plants Under Salt Stress. Springer, New York, pp 25-87 https://doi.org/10.1007/978-1-46144747-42

Hassanein RA, Bassony FM, Barakat DM, Khalil RR (2009) Physiological effects of nicotinamide and ascorbic acid on Zea mays plant grown under salinity stress. 1- changes in growth, some relevant metabolic activities and oxidative defense systems. Res J Agric Biol Sci 5(1):72-80

Homme PM, Gonzalez B, Billard J (1992) Carbohydrate content, frutane and sucrose enzyme activities in roots, stubble and leaves of rye grass (Lolium perenne L.) as affected by sources / link modification after cutting. J Plant Physiol 140:282-291

Hu Y, Schmidhalter U (2005) Drought and salinity: a comparison of their effects on mineral nutrition of plants. J Plant Nutr Soil Sci 168:541-549

Kawasaki T (1992) Modern chromatographic analysis of vitamins, vol 60, 2nd edn. Marcel Dekker, Inc, New York, NY, pp 319-354

Khafagy MA, Mohamed ZAA, Farouk S, Amrajaa HK (2017). Effect of Pre-treatment of Barley Grain on Germination and Seedling Growth Under Drought Stress. AdvancesinAppliedSciences 2017;2:33-42.

Khafagy MA, ZAI M, Farouk S, Amrajaa HK (2016) Effect of pre-treatment of barley grain on germination and seedling growth under drought stress. Adv App Sci 2(3):33-42

Martinis J, Gas-Pascual E, Szydlowski N, Crèvecoeur M, Gisler A, Bürkle L, Fitzpatrick TB (2016) Long-distance transport of thiamine (vitamin B1) is concomitant with that of polyamines. Plant Physiol 171:542-553

Minolta Camera Co (1989) Manual for chlorophyll meter SPAD-502. Minolta Camera Co, Osaka

Mohsen AA, Ebrahim MKH, Ghoraba WFS (2018) Effect of salinity stress on Vicia faba productivity with respect to ascorbic acid treatment. Iran J Plant Physiol 3(3):725-736

Munns, R. (2002) Comparative physiology of salt and water stress. Plant Cell and Environment 28:239-250.

Muting D, Kaiser E (1963) Spectrophotometric methods of determining of amino$\mathrm{N}$ in biological materials by means of the ninhydrin reactions. Hoppe Seylers Z Physiol Chem 332:276-281

Oertli II (1997) Exogenous application of vitamins as regulators for growth and development of plants. Pelanzenernahr Boodenk 150:375-391

Parida AK, Das AB (2005) Salt tolerance and salinity effects on plants: a review. Ecotoxicol Environ Saf 60:324-349

Patakas A, Nikolaou N, Zioziou E, Radoglou K, Noitsakis B (2002) The role of organic solute and ion accumulation in osmotic adjustment in droughtstressed grapevines. Plant Sci 163:361-367

Rady MM, Sadak MS, El-Bassiouny HMS, Abd El-Monem AA (2011) Alleviation the adverse effects of salinity stress in sunflower cultivars using nicotinamide and a-tocopherol. Aust J Basic Appl Sci 5:342-355

Rady MM, Sadak MS, El-Lethy SR, Abdelhamid EM, Abdelhamid MT (2015) Exogenous a-tocopherol has a beneficial effect on Glycine max (L.) plants irrigated with diluted sea water. J Hort Sci Biotech 90:195-202

Robinson FA (1973) Vitamins. In: Lawrence, Miller P (eds) Phytochemistry, vol III. Van- Reinhold Co, New York, pp 195-220

Sadak MS (2016) Physiological role of yeast extract and nicotinamide on Pisum sativum L. plants under heat stress. Int J Pharm Tech Res 9(9):170-178

Sadak MS (2019) Physiological role of trehalose on enhancing salinity tolerance of wheat plant. Bull National Research Centre 43:53

Sadak MS, El-Bassiouny HMS, Dawood MG (2019) Role of trehalose on antioxidant defense system and some osmolytes of quinoa plants under water deficit. Bull Natl Res Cent 43:5

Sadak MS, Rady MM, Badr NM, Gaballah MS (2010) Increasing sunflower salt tolerance using nicotinamide and a-tocopherol. Int J Acad Res 2(4):263-270

Samiullah SS, Ansari MM, Afridi RK (1988) B-vitamin in relation to crop productivity. Ind Res Life Sci:151-174

Sayed SA, Gadallah MAA (2002) Effects of shoot and root application of thiamin on salt-stressed sun-flower plants. Plant Growth Regul 36(1):71-80

Semida WM, Taha RS, Abdelhamid MT, Rady MM (2014) Foliar-applied atocopherol enhances salt-tolerance in Vicia faba L. plants grown under saline conditions. South Afr. S Afr J Bot 95:24-31 
Senaratna T, Touchell D, Bunn E, Dixon K (2000) Acetyl salicylic acid (aspirin) and salicylic acid induce multiple stress tolerance in bean and tomato plants. Plant Growth Regul 30:157-161

Silva C, Martinez V, Carvajal M (2008) Osmotic versus toxic effects of $\mathrm{NaCl}$ on pepper plants. Biol Plant 52(1):72-79

Soliman IE, Morsi AR, Khaffagy AE (2015) Effect of competitive abilities of some soybean genotypes, plant densities and weed control treatments on soybean (Glycine Max L. Merr) and its associated weeds. J Plant Prod 6(8): 1413-1429

Srivastava DK, Gupta VK, Sharma DR (1995) In vitro selection and characterization of water stress tolerance callus cultures of tomato (Lycopersicum esculentum L). Indian J Plant Physiol 38(2):99-104

Sweet WJ, Morrison JC, Labaritch JM, Matthews MA (1990) Altered synthesis and composition of cell wall of grapevines Vitis vinifera $L$. during expression and growth inhibiting water deficits. Plant Cell Physiol 31:407-414

Taie H, Abdelhamid MT, Dawood MG, Nassar RM (2013) Presowing seed treatment with proline improves some physiological, biochemical and anatomical attributes of faba bean plants under sea water stress. J Appl Sci Res 9(4):2853-2867

Torres-Schumann S, Godoy J, Pentor-Toro J, Moreno F, Rodrigo R, GarciaHerdugo $\mathrm{G}$ (1989) $\mathrm{NaCl}$ effects on tomato seed germination, cell activity and ion allocation. J Plant Physiol 135:228-232

Van Hoorn JW, Katerji N, Hamdy A, Mastrorilli M (2001) Effect of salinity on yield and nitrogen uptake of four grain legumes and on biological nitrogen contribution from the soil. Agric Water Manag 51:87-98

Vartainan N, Hervochon P, Marcotte L, Larher F (1992) Proline accumulation during drought rhizogenesis in Brassica napus var. oleifera. J Plant Physiol 140:623-628

Verma SK, Chaudhary M, Prakash V (2012) Study of the alleviation of salinity effect due to enzymatic and non-enzymatic antioxidants in glycine max. Res J Pharm Bio Chem Sci 3:1177-1185

Yemm EW, Willis AJ (1954) The estimation of carbohydrates in plant extracts by anthrone. Biochem J 57(3):508-514

Youssef AA, Talaat IM (2003) Physiological response of rosemary plants to some vitamins. Egypt Pharm J 1:81-93

\section{Submit your manuscript to a SpringerOpen ${ }^{\circ}$ journal and benefit from:}

- Convenient online submission

- Rigorous peer review

- Open access: articles freely available online

- High visibility within the field

- Retaining the copyright to your article

Submit your next manuscript at $\boldsymbol{\nabla}$ springeropen.com 